\title{
The Influence of Celebrity Endorser and Attitudes on Advertising towrads Attitudes on Brand and Repurchase Intention
}

\section{Lintang Pamugar Mukti Aji*}

Universitas Nahdlatul Ulama Surakarta

\section{A R T I C L E I N F O \\ Article history: \\ Received 19 Januari 2018 \\ Received in revised form 27 Februari \\ Accepted 30 April 2018 Available online $27 \mathrm{Mei}$ 2018}

Keywords:

celebrity endorser, attitude toward advertising attitude toward brand and repurchase intention

\begin{abstract}
A B S T R A C T
The purpose of this research was to analyze the effect of celebrity endorser and attitude toward advertising on attitude toward brand and repurchase intention. This research used design explanatory. Population were IM3 prepaid card customers in Surakarta. The sampling technique was convenience sampling with 100 respondents. Techniques of data collection used observation, documentation, questionnaires and literature study. Analysis used validity test, reliability test, t-test, f-test, R Square test and path analysis. The results showed that celebrity endorser significant affected on attitude toward brand. Attitude toward advertising significant affected on attitude toward brand. Celebrity endorser significant affected on repurchase intention. Attitude toward advertising significant affected on repurchase intention. Attitude toward brand significant affected on repurchase intention. Celebrity endorser and attitude toward advertising affected on attitude toward brand simultaneous. Celebrity endorser, attitude toward advertising and attitude toward brand affected on repurchase intention simultaneous. The coefficient of determination of total results $\left(R^{2}\right)$ was $59,0 \%$ so repurchase intention can be explained variable celebrity endorser, attitude toward brand within attitude toward brand as a intervening variables and the remaining $41.0 \%$ was explained variables outside the model. Celebrity endorser is a proven direct and indirect effect on repurchase intention.
\end{abstract}

\footnotetext{
* Corresponding author.

E-mail addresses: lintangpamugar@yahoo.co.id (Lintang Pamugar Mukti Aji)
} 


\section{Introduction}

In the era of globalization, business competition that is increasingly dynamic, complex and uncertain, does not only provide opportunities but also challenges faced by companies to always get the best way in order to capture and maintain market segment.

Every company tries to attract the attention of (potential) customers in various ways; one of them is by providing information about products. Providing information about these products can be done through various forms of marketing communication programs including: advertising, sales promotions, personal selling, public relations and direct marketing "(Kotler, 2005: 219). Of the various existing marketing communication programs, advertising is one of the most common ways companies use to direct persuasive communication to the target audience. This media is considered to be most effective in influencing customers to make purchases.

The ability of advertisements to get across messages to customers makes the field play an important role for the success of the company in providing information about products to customers. Advertising reaches buyers who are geographically dispersed and can build a long-term image for the product or trigger quick sales. Television and its advertising are proved to be the most effective and efficient mass communication media for providing product information and the image of a company (Sari and Djatikusuma, 2013: 1).

The choice of the delivery source of the message in the advertisement must be considered because it influences the success of the company, especially in marketing its products. Using supporters (endorsers) is an effective way in this process and is in great demand by advertising companies today. Endorser plays a major role in the success of advertising. Celebrities as product endorsers are often called celebrity endorsers. Endorsers are often referred to as direct sources, namely a speaker who delivers a message and or demonstrates a product or service. Endorser is also interpreted as someone who is chosen to represent the image of a product (product image) and usually from among public figures who have prominent characters and have a strong attraction. (Hardiman, 2006: 38).

The use of celebrity supporters (celebrity endorser) must go through several considerations, including the level of celebrity popularity whether the chosen celebrity can represent the character of the product being advertised (Royan, 2004: 8). Royan also stated that the use of a celebrity in advertising can help in forming two things, namely forming an attitude on the brand or just to increase sales volume in a very short time. The choice of this celebrity can be done through various considerations including the choice will be given to a rising celebrity with consideration of whether the chosen celebrity can represent the character of the product being advertised and the thing that is related to the company's finances. Celebrity endosers utilize a person who has a positive influence due to the achievements and images he has achieved (Darmansyah, 2014).

Perceptions about endorsers also affect the formation of attitudes of target customers towards their attitude to advertising because of the popularity of endorsers used. Customers only remember the advertising star (endorser) but forget the product brand. In this case creativity in advertising is the core of the effectiveness of an advertisement because it can draw the attention of customers and make advertising more memorable. Creative advertising will indeed draw attention from images and content of advertisements but will interfere with the attention to the brand that will be advertised so that it will reduce the effectiveness of the brand being advertised. This is in line with the opinion that says that advertising creativity is only to fulfill the artistic needs of the maker. (Ishak, 2005: 32).

Consumer attitudes toward brands can arise after knowing the brand either directly hear or see the advertising message (information) submitted by the manufacturer. The market segment of a brand will increase when the brand attitudes of customers become positive (Howard in Kurniawati, 2009: 19). In strengthening the brand through brand share or market share, companies need to create activities that will foster a positive attitude towards the brand; one of them is by using advertising. Stimuli in advertisements either verbal or non-verbal are specifically designed so that the product attributes that are wanted to be highlighted can be positively appreciated by customers such as claims about products, credible advertising stars as well as the company's credibility (Ferrinadewi, 2008: 163).

Indosat is one of cellular operator companies that provide telecommunications services to customers. One of the many products produced by Indosat is the IM3 prepaid card (Indosat Multi Media Mobile). In the face of competition with other cellular operators, PT. Indosat Tbk. with IM3 products also use endoser celebrity including JKT 48 girl band, Fatin and also a rising celebrity star, Caesar who is famous for his caesar shake. This is done to further introduce IM3 products to customers. IM3 is one of the cellular operators in the youth segment and IM3 products control 2/3 of the total customers of PT. Indosat Tbk. which indeed focuses its market for young people. The youth market is the second largest cellular market after the labor market (Nikmah, 2013: 9). 
The negative phenomenon shown by PT. Indosat also seems to occur at the level of customer loss (churn rate). The company's report shows that the churn rate experienced by PT. Indosat is quite high and there is a tendency to continue to increase. Even the investment site for Indonesia stated that Indosat lost several percent of its mobile phone subscriber market in the last year. The results of the Annual General Meeting of Shareholders (AGMS) stated that PT Indosat Tbk (ISAT) experienced a decrease in the number of customers in the first quarter of this year by 2.5 million customers. This is inversely proportional to the fourth quarter of 2013 which grew by 3 million customers (Nikmah, 2013: 6). This is certainly one of the things that is not good for Indosat because Indosat is one of the oldest telecommunication services companies in Indonesia.

\section{Method}

This research is an explanatory research that explains the causal relationship between independent and dependent variables. The purpose of this study is to test the hypothesis of the influence of independent variables on dependent variables. Data and information needed are obtained from IM3 customers documents and their responses in Surakarta. The location of the study was in Surakarta and the object in this study were consumers who used IM3 prepaid card. The population in this study is IM3 prepaid card customers in Surakarta. The sampling technique used convenience sampling where researchers took samples according to the criteria as IM3 prepaid card users who were accidentally encountered by researchers.

This study uses data collection techniques such as documentation, questionnaire and literature study techniques. The data analysis technique was by testing the research instruments that were tested for validity and reliability. The research prerequisite test used in this research is linearity test. Linearity test is a step to know whether the status of a distribution of a research data is linear or not. Meanwhile, hypothesis testing uses one path, $\mathrm{t}$ test, $\mathrm{F}$ test and coefficient of determination.

\section{Results and Discussion}

Validity test is used to measure whether a questionnaire is valid or not. An instrument is said to be valid if the $r$ count is greater than $r_{\text {table }}$ and the positive value, so the question item or the indicator is declared valid, while the validity test results can be seen in the table as follows:

Table 1. Test Results of Celebrity Endorser Validity

\begin{tabular}{|l|l|l|l|}
\hline Question Item & $\mathrm{R}_{\text {count }}$ & $\mathrm{r}_{\text {table }}$ & Annotation \\
\hline $\mathrm{X}_{1 \_1}$ & 0,212 & 0,194 & Valid \\
$\mathrm{X}_{1 \_2}$ & 0,260 & 0,194 & Valid \\
$\mathrm{X}_{1 \_3}$ & 0,250 & 0,194 & Valid \\
$\mathrm{X}_{1 \_4}$ & 0,303 & 0,194 & Valid \\
$\mathrm{X}_{1 \_5}$ & 0,643 & 0,194 & Valid \\
$\mathrm{X}_{1 \_6}$ & 0,564 & 0,194 & Valid \\
$\mathrm{X}_{1 \_}$ & 0,556 & 0,194 & Valid \\
\hline
\end{tabular}

Based on the above table it can be seen that the whole questionnaire items of celebrity endorser have a value of $r_{\text {count }}>r_{\text {table }}$ so that the item is declared valid.

Table 2. Test Results of Attitudes Validity on Advertising

\begin{tabular}{|l|l|l|l|}
\hline Question Item & $\mathrm{r}_{\text {hitung }}$ & $\mathrm{r}_{\text {tabel }}$ & Annotation \\
\hline $\mathrm{X}_{2} 1$ & 0,373 & 0,194 & Valid \\
$\mathrm{X}_{2} 2$ & 0,406 & 0,194 & Valid \\
$\mathrm{X}_{2} 3$ & 0,536 & 0,194 & Valid \\
$\mathrm{X}_{2} 4$ & 0,513 & 0,194 & Valid \\
$\mathrm{X}_{2} 5$ & 0,400 & 0,194 & Valid \\
$\mathrm{X}_{2} 6$ & 0,219 & 0,194 & Valid \\
$\mathrm{X}_{2 \_} 7$ & 0,243 & 0,194 & Valid \\
\hline
\end{tabular}

Based on the table, it can be seen that the overall questionnaire items of attitude on the advertising have a value of $r_{\text {count }}>r_{\text {table }}$ so that the item is declared valid. 
Table 3. Test Results of Attitude Validity on Brands

\begin{tabular}{|l|l|l|l|}
\hline Question Item & $r_{\text {hitung }}$ & $r_{\text {tabel }}$ & Annotation \\
\hline$X_{3 \_} 1$ & 0,536 & 0,194 & Valid \\
$X_{3 \_}$ & 0,565 & 0,194 & Valid \\
$X_{3} 3$ & 0,586 & 0,194 & Valid \\
$X_{3 \_}$ & 0,491 & 0,194 & Valid \\
$X_{3 \_}$ & 0,449 & 0,194 & Valid \\
$X_{3 \_}$ & 0,252 & 0,194 & Valid \\
\hline
\end{tabular}

Based on the table it can be seen that the overall questionnaire items of attitude on brands have a value of $r_{\text {count }}>r_{\text {table }}$ so that the item is declared valid.

Table 4. Test Results of Validity of Repurchase Intention

\begin{tabular}{|l|l|l|l|}
\hline Question Item & $r_{\text {hitung }}$ & $r_{\text {tabel }}$ & Annotation \\
\hline Y_1 & 0,254 & 0,194 & Valid \\
Y_2 & 0,611 & 0,194 & Valid \\
Y_3 & 0,625 & 0,194 & Valid \\
Y_4 & 0,586 & 0,194 & Valid \\
Y_5 & 0,301 & 0,194 & Valid \\
Y_6 & 0,280 & 0,194 & Valid \\
\hline
\end{tabular}

Based on the table it can be seen that the overall questionnaire items of customer loyalty have a value of $r_{\text {count }}>r_{\text {table }}$ so that the item is declared valid.

Table 5. Test Results of Reliability

\begin{tabular}{|l|l|l|l|}
\hline Variabel & Alpha Cronbach & Criterion & Annotation \\
\hline Celebrity endorser & 0,693 & 0,60 & Reliabel \\
Attitude on advertising & 0,675 & 0,60 & Reliabel \\
Job satisfaction & 0,742 & 0,60 & Reliabel \\
Customer loyalty & 0,712 & 0,60 & Reliabel \\
\hline
\end{tabular}

From the test results of the reliability it can be seen that all statements regarding celebrity endorser, attitudes on advertisements, attitudes on brands and customer loyalty have a Cronbach Alpha value $>$ critical value $(0.60)$ so that the overall variable is reliable.

From the results of the linearity test shows the $\mathrm{R}^{2}$ value is 0,000 with the number of samples 100 , the value of $c^{2}$ count $=100 \times 0,000=0.00$ while the value of $c^{2}$ table is 123.86 . The value of $c^{2}$ counts $<c^{2}$ table so it can be concluded that the correct model is a linear model.

The analysis of results of the regression equation is as follows:

First Equation

Table 6. Regression Results of Equation I

\section{Coefficients}

\begin{tabular}{|c|c|c|c|c|c|c|}
\hline \multirow[b]{2}{*}{ Model } & & \multicolumn{2}{|c|}{$\begin{array}{l}\text { Unstandardized } \\
\text { Coefficients }\end{array}$} & \multirow{2}{*}{$\begin{array}{c}\begin{array}{c}\text { Standardized } \\
\text { Coefficients }\end{array} \\
\text { Beta } \\
\end{array}$} & \multirow[b]{2}{*}{$t$} & \multirow[b]{2}{*}{ Sig. } \\
\hline & & $\mathrm{B}$ & Std. Error & & & \\
\hline 1 & (Cons tant) & 5,532 & 2,446 & & 2,262 &, 026 \\
\hline & Celebrity Endorser & ,228 &, 102 & ,252 & 2,248 & 027 \\
\hline & Sikap pada iklan & ,371 & ,113 & ,368 & 3,273 & ,001 \\
\hline
\end{tabular}

a. Dependent Variable: Sikap Pada Merek 
Based on the results of the regression coefficients it can be seen that the attitude on the advertisement has more dominant influence on the attitude of the brand compared to celebrity endorser, this is because the coefficient value of attitude regression on the ad $(0.368)$ is higher than the value of regression coefficient of celebrity endorser (0.252).

Table 7. Results of Equation Regression II

\section{Coefficients $^{\mathrm{a}}$}

\begin{tabular}{|rl|r|r|r|r|r|}
\hline \multirow{2}{*}{ Model } & \multicolumn{2}{|c|}{$\begin{array}{c}\text { Unstandardiz ed } \\
\text { Coefficients }\end{array}$} & \multicolumn{2}{c|}{$\begin{array}{c}\text { Standardized } \\
\text { Coefficients }\end{array}$} & \\
\cline { 3 - 7 } & & \multicolumn{1}{|c|}{ B } & Std. Error & Beta & \multicolumn{1}{c|}{ S } & Sig. \\
\hline 1 & (Cons tant) & $-2,050$ & 1,480 & & $-1,386$ &, 169 \\
& Celebrity Endorser &, 243 &, 061 &, 277 & 3,953 &, 000 \\
& Sikap pada iklan &, 525 &, 070 &, 536 & 7,449 &, 000 \\
& Sikap Pada Merek &, 179 &, 060 &, 184 & 2,983 &, 004 \\
\hline
\end{tabular}

a. Dependent Variable: Minat Beli Ulang

Based on the results of the regression coefficients it can be seen that the attitude on the advertisement has more dominant influence on repurchase intetioncompared to celebrity endorser and attitude on the brand, this is because the coefficient value of attitude regression on advertising (0.536) is higher than the coefficient value of regression of celebrity endorser (0.277) and the coefficient value of regression of attitude on the brand (0.184).

Table 8. Test Results $\mathrm{t}$

\begin{tabular}{|l|l|l|l|l|}
\hline Equation & Inter-variable Relations & Beta & t count & Sig \\
\hline I & Celebrity endorser $\rightarrow$ attitude on the brand & 0,252 & 2.248 & $0,027^{* *}$ \\
& Attitude on advertisement $\rightarrow$ attitude on the brand & 0,368 & 3.273 & $0,001^{* *}$ \\
\hline II & Celebrity endorser $\rightarrow$ repurchase interest & 0,277 & 3.953 & $0,000^{* * *}$ \\
& Attitude on advertisement $\rightarrow$ repurchase interest & 0,536 & 7.449 & $0,000^{* * *}$ \\
& Attitude on the brand $\rightarrow$ repurchase interest & 0,184 & 2.983 & $0,004^{* *}$ \\
\hline
\end{tabular}

Based on the results of the tests that have been carried out, the results of the test are (1) Hypothesis 1: The results of the influence of celebrity endorser on the attitude of the brand obtained a significance value of $0.027<0.05$, so that celebrity endorser affects the attitude of IM3 prepaid card brands (H1 proven to be true); (2) Hypothesis 2: The results of the influence of attitudes on advertising on the attitude of the brand obtained a significance value of $0.001<0.05$, so that the attitude on the advertisement affects the attitude of the IM3 prepaid card brand (H2 proven to be true); (3) Hypothesis 3: The result of the influence of celebrity endorser on repurchase intetionobtained a significance value of $0.000<0.05$, so that celebrity endorser affects the interest in repurchasing IM3 prepaid cards (H3 proven to be true); (4) Hypothesis 4: The results of the influence of attitudes on advertising on repurchase intetionobtained a significance value of $0.000<0.05$, so that the attitude on the advertisement affected the interest in repurchasing IM3 prepaid cards (H4 proved to be true); (5) Hypothesis 5: The results of the influence of the attitude on the brand on repurchase intetionobtained a significance value of $0.004<0.05$, so that the attitude on the brand influences the interest in repurchasing IM3 prepaid cards (H5 proved to be true).

Table 9. F Test Results of Regression I

ANOVA

\begin{tabular}{|ll|r|r|r|r|r|}
\hline \multicolumn{1}{|c|}{} & \multicolumn{1}{c|}{$\begin{array}{c}\text { Sum of } \\
\text { Model }\end{array}$} & Squares & df & Mean Square & F & Sig. \\
\hline 1 & Regression & 277,808 & 2 & 138,904 & 23,123 &, $000^{\mathrm{a}}$ \\
& Residual & 582,702 & 97 & 6,007 & & \\
& Total & 860,510 & 99 & & & \\
\hline
\end{tabular}

a. Predictors: (Constant), Sikap pada iklan, Celebrity Endorser

b. Dependent Variable: Sikap Pada Merek 
Simultaneous test results (Test F) of regression I showed that the value of $F_{\text {count }}$ is 23,123 with a significance value of $0,000<0,05$ so it can be concluded that celebrity endorsers and attitudes on advertising together influence the attitude of the brand.

Table 10. F Test Results of Regression II

ANOVA

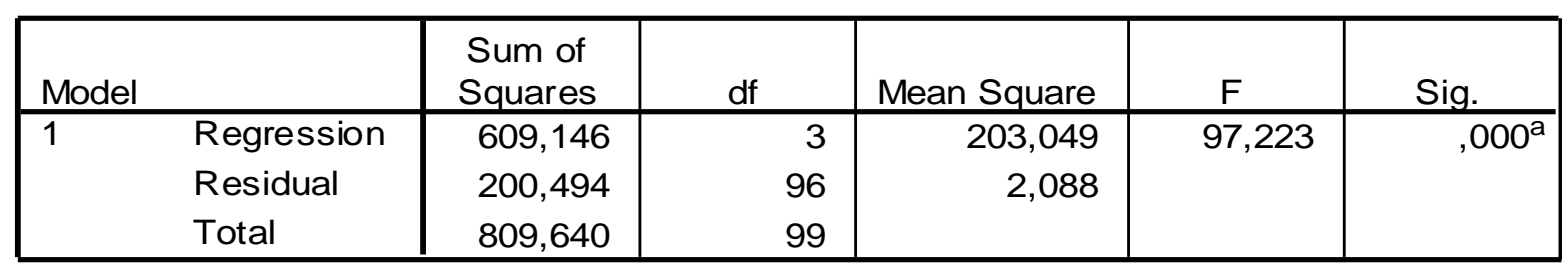

a. Predictors: (Constant), Sikap Pada Merek, Celebrity Endorser, Sikap pada iklan

b. Dependent Variable: Minat Beli Ulang

Simultaneous test results (Test F) of regression II showed that the value of $\mathrm{F}_{\text {count }}$ is 97.223 with a significance value of $0.000<0.05$ so that it can be concluded that celebrity endorser, attitude on advertising and attitude towards the brand together influence the repurchase intention.

Table 11. Coefficient of Determination of Equation I

Model Summary

\begin{tabular}{|l|r|r|r|r|}
\hline Model & $\mathrm{R}$ & $\mathrm{R}$ Square & $\begin{array}{c}\text { Adjusted } \\
\mathrm{R} \text { Square }\end{array}$ & $\begin{array}{c}\text { Std. Error of } \\
\text { the Estimate }\end{array}$ \\
\hline 1 &, $568^{\mathrm{a}}$ &, 323 &, 309 & 2,451 \\
\hline
\end{tabular}

a. Predictors: (Cons tant), Sikap pada iklan, Celebrity Endorser

The test results of coefficient of determination of equation I showed the value of R Square $(0.323)$ or $32.3 \%$, which means that, celebrity endorsers and attitudes on advertising have an effect of $32.3 \%$ on the attitude of the brand. While the remaining $67.7 \%$ is explained by other variables that are not included in the regression model. So the value of $\varepsilon 1=\sqrt{1-R_{1}^{2}}=\sqrt{1-0,323}=\sqrt{0,677}=0,823$

Table 12. Coefficient of Determination of Equation II

Model Summary

\begin{tabular}{|l|r|r|r|r|}
\hline Model & $\mathrm{R}$ & $\mathrm{R}$ Square & $\begin{array}{c}\text { Adjusted } \\
\mathrm{R} \text { Square }\end{array}$ & $\begin{array}{c}\text { Std. Error of } \\
\text { the Estimate }\end{array}$ \\
\hline $\mathbf{1}$ &, $867^{\mathrm{a}}$ &, 752 &, 745 & $\mathbf{1 , 4 4 5}$ \\
\hline
\end{tabular}

a. Predictors: (Constant), Sikap Pada Merek, Celebrity Endorser, Sikap pada iklan

b. Dependent Variable: Minat Beli Ulang

The test results of coefficient of determination of equation II showed the value of R Square (0.752) or $75.2 \%$, which means celebrity endorser, attitude on advertising and attitude on the brand influence by $75.2 \%$ of repurchase intention. While the remaining $24.8 \%$ is explained by other variables not included in the regression model. So the value of $\varepsilon 2=\sqrt{1-R_{1}{ }^{2}}=\sqrt{1-0,752}=\sqrt{0,248}=0,498$

The total R2 value of 0.590 means that the celebrity endorser variable and the attitude on the advertisement have an effect of $59.0 \%$ on repurchase intetionwith the brand's attitude as intervening while the remaining $41.0 \%$ is explained by variables outside the model, such as customer satisfaction and loyalty. 
Table 13. Table of Correlation Coefficient

Correlations

\begin{tabular}{|ll|r|r|r|r|}
\hline & & $\begin{array}{c}\text { Celebrity } \\
\text { Endorser }\end{array}$ & $\begin{array}{c}\text { Sikap } \\
\text { pada iklan }\end{array}$ & $\begin{array}{c}\text { Sikap Pada } \\
\text { Merek }\end{array}$ & $\begin{array}{c}\text { Minat Beli } \\
\text { Ulang }\end{array}$ \\
\hline Celebrity Endorser & Pearson Correlation & 1 &, $668^{\star \star}$ &, $498^{\star \star}$ &, $726^{\star \star}$ \\
& Sig. (2-tailed) & &, 000 &, 000 &, 000 \\
& $\mathrm{~N}$ & 100 & 100 & 100 & 100 \\
\hline Sikap pada iklan & Pearson Correlation &, $668^{\star \star}$ & 1 &, $536^{\star \star}$ &, $819^{\star \star}$ \\
& Sig. (2-tailed) &, 000 & &, 000 &, 000 \\
& $\mathrm{~N}$ & 100 & 100 & 100 & 100 \\
\hline Sikap Pada Merek & Pearson Correlation &, $498^{\star \star}$ &, $536^{\star \star}$ & 1 &, $609^{\star \star}$ \\
& Sig. (2-tailed) &, 000 &, 000 & &, 000 \\
& $\mathrm{~N}$ & 100 & 100 & 100 & 100 \\
\hline Minat Beli Ulang & Pearson Correlation &, $726^{\star \star}$ &, $819^{\star \star}$ &, $609^{\star \star}$ & 1 \\
& Sig. (2-tailed) &, 000 &, 000 &, 000 & 100 \\
& $\mathrm{~N}$ & 100 & 100 & 100 & 100 \\
\hline
\end{tabular}

${ }^{* *}$. Correlation is significant at the 0.01 level (2-tailed).

Based on the results of the table, it can be explained as follows (1) Correlation test of celebrity endorser with the attitude on the brand showed correlation value (0.498) with significance $(0.000)$, this means that there is a fairly strong and significant relationship between celebrity endorser and attitude towards the brand; (2) Correlation test of the attitude on the advertising with the attitude on the brand showed the correlation value $(0.536)$ with significance $(0.000)$, this means that there is a fairly strong and significant relationship between attitudes on advertising and attitude to the brand; (3) Correlation test of celebrity endorser with repurchase intetion showed correlation value $(0.726)$ with significance $(0.000)$, tihis means that there is a strong and significant relationship between celebrity endorser and repurchase intention; (4) Test the correlation of attitudes on advertisements with repurchase intention showed correlation values $(0.819)$ with significance $(0.000)$, this means that there is a very strong and significant relationship between attitude on advertisements and repurchase intention; (5) Test the correlation of attitudes on brands with repurchase intention showed correlation values $(0.609)$ with significance (0.000), this means that there is a strong and significant relationship between attitudes on brands with repurchase intention.

The complete results of path analysis in this study can be explained in detail as in the picture below:

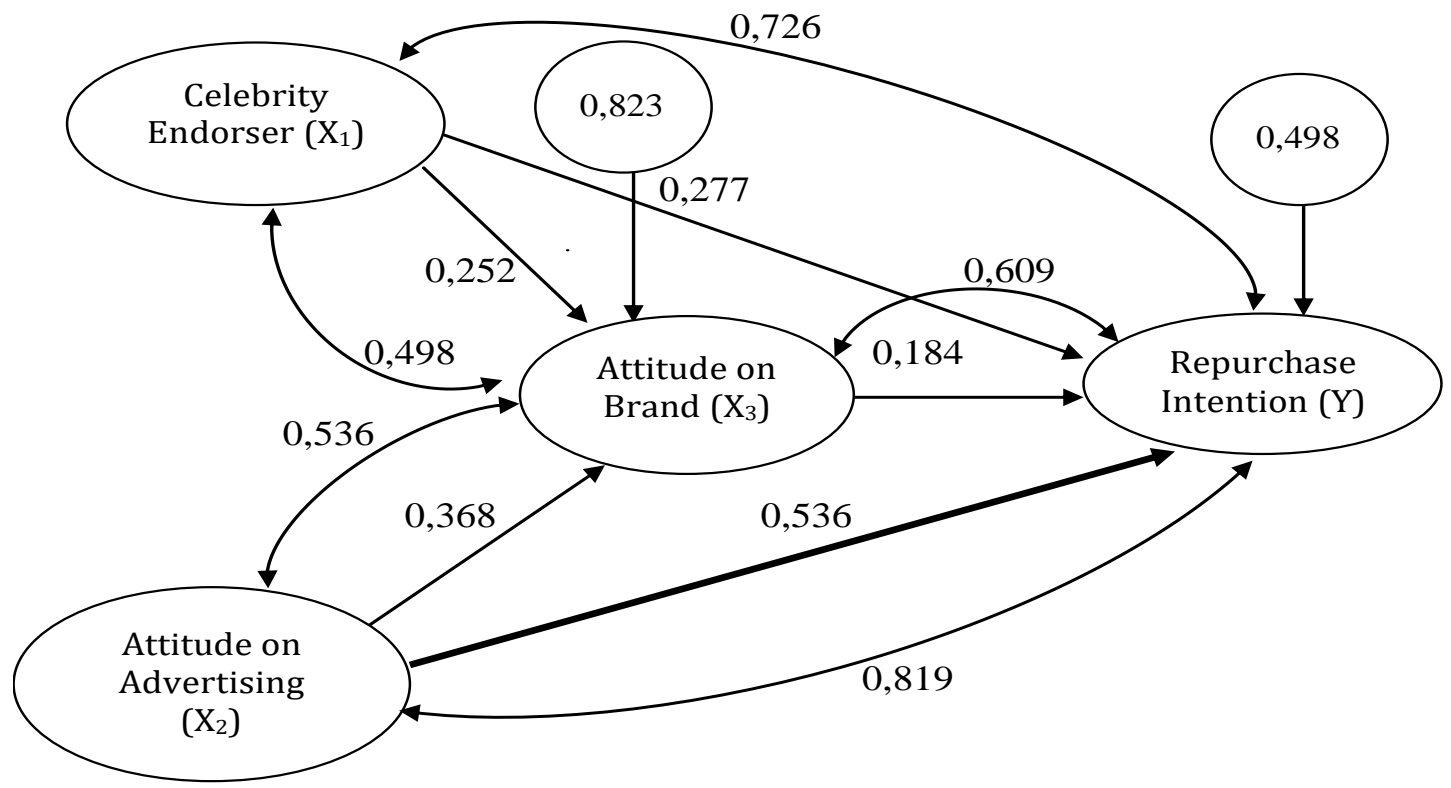

Firure 1.2. Result of Path Analysis 


\section{Conclusions and Suggestions}

Individually, testing the hypothesis of the research shows that: (1) Celebrity endorsers influence the attitude of the IM3 prepaid card brand so that $\mathrm{H}_{1}$ is proven to be true; (2) Attitudes on advertisements affect the attitude of IM3 prepaid card brands so $\mathrm{H}_{2}$ is not proven to be true; (3) Celebrity endorsers influence the intention in repurchasing IM3 prepaid cards so that $\mathrm{H}_{3}$ is proven to be true; (4) Attitudes on advertisements affect the intention in repurchasing IM3 prepaid cards, so $\mathrm{H}_{4}$ is proven to be true; (5) Attitudes on brands affect IM3 prepaid cards so that $\mathrm{H}_{5}$ is proven to be true.

Simultaneously or together, the results of these tests are as follows: (1) Celebrity endorsers and attitudes to advertising jointly influence the attitude of IM3 prepaid card brands; (2) Celebrity endorsers and attitudes to advertising and attitudes to brands together influence the intention in repurchasing IM3 prepaid cards.

The results of the coefficient of determination showed total value of $\mathrm{R}^{2}$ by 0.590 , this means that the variable of celebrity endorser and the attitude on the advertisement has an effect of $59.0 \%$ on customers' loyalty with the brand's attitude as intervening while the remaining $41.0 \%$ is explained by variables outside the model, such as satisfaction and quality service.

The results of path analysis can be summarized as follows; (1) Celebrity endorsers have been proven to have a direct effect on intention in repurchasing IM3 prepaid cards and can also indirectly affect on intention in repurchasing. The Variable of celebrity endorser that directly affects repurchase intetion has a regression coefficient of 0.277 so that it is greater than the regression coefficient of the influence of celebrity endorser variables on repurchase intetion through attitudes on the brand of 0.046; (2) The attitude towards the advertisement has a direct effect on the intention in repurchasing IM3 prabyar cards and can also have an indirect effect on repurchase intention. Attitude variables on advertisements that directly affect repurchase intetion have a regression coefficient of 0.536 so that it is greater compared to regression coefficient of the influence of attitude variables on advertisements on repurchase intetion through attitudes on the brand of 0.068 .

Suggestions that can be given in this study include (1) Looking at the respondents' positive responses to celebrity endorsers, attitudes to advertising, attitudes to brands and repurchase intention, especially attitudes to advertisements, so the company should make entertaining advertisements that are in accordance with the soul of young people and interesting to be able to increase the attractiveness of the product so that consumers make repeat purchases; (2) Further researchers should conduct research on factors that can affect repurchase intention such as customers' satisfaction and loyalty.

\section{Refrence}

Assael H. 2004. Consumers Behavior and Marketing Action, Kent Publishing Company, Boston Massachusset, AS.

Darmansyah, Muhartini Salim, Syamsul Bachri. 2014. Pengaruh Celebrity Endorser terhadap Keputusan Pembelian Produk di Indonesia (Penelitian Online). Jurnal Aplikasi Manajemen, Vol.12 No, 2.

Dominanto. 2008, Perbedaan Sikap Terhadap Iklan, Merek, dan Niat Beli Konsumen Pada Iklan Dengan Fear Appeal, Jurnal Ekonomi Bisnis, Vol.2 No, 2, hal : 152-168.

Durianto, Darmadi, Sugiarto dan Tony Sitinjak. 2004. Strategi Menaklukan Pasar Melalui Riset Ekuitas dan Perilaku Merek, Jakarta: Gramedia Pustaka Utama.

Ferdinand, A. 2002, Structural Equation Modeling dalam Penelitian Manajemen : Aplikasi Model-model Rumit dalam Penelitian untuk Tesis Magister dan Disertasi Doktor", Semarang : BP Undip

Ferrinadewi, Ema, 2008, Merek \& Psikologi Konsumen, Yogyakarta : Graha Ilmu.

Hardiman, Ima 2006, 400 Istilah PR Media dan Periklanan, Jakarta : Gagas Ulung.

Ishak, Asmai, 2005, Pentingnya Kepuasan Konsumen Dan Implementasi Strategi Pemasarannya, Jurnal Siasat Bisnis On Marketing, Vol 2, No. 1, hal : 1-11.

Kotler, Philip, 2005, Manajemen Pemasaran, Alih Bahasa Benyamin Molan, Jakarta : Indeks Kelompok Gramedia. 
Kotler and Keller, Kevin Lane Keller, 2008, Manajemen Pemasaran. Jakarta : Penerbit Indeks.

Kurniawati, Dyah, 2009, Studi Tentang Sikap Terhadap Merek Dan Implikasinya Pada Minat Beli Ulang (Kasus pada produk mi instan Indomie di Kota Semarang), Tesis, Program Studi Magister Manajemen Program Pascasarjana, Semarang : Universitas Diponegoro, tidak dipublikasikan.

Nikmah, Sri, 2013, Analisis Pengaruh Persepsi Harga, Kualitas Produk, Kualitas Layanan Terhadap Minat Beli Ulang Kartu Prabayar Indosat Im3 (Studi Kasus pada Mahasiswa Universitas Diponegoro Semarang), Skripsi, Fakultas Ekonomika dan Bisnis Universitas Diponegoro Semarang.

Nurani, Eka Setya dan Jony Oktavian Haryanto, 2008, Pengaruh Celebrity Endorser, Brand Association, Brand Personality Dan Product Characteristics Dalam Menciptakan Intensi Pembelian (Studi pada Iklan Kuku Bima Ener-G Rosa Versi Chris John), Journal of Business Strategy and Execution, Vol 2, No. 2 , hal : $104-125$.

Robbins, 2005, Perilaku Organisasi, Alih Bahasa Hadyana Pudjaatmaka, Erlangga, Jakarta.

Rosi, Fatchur dan Anik Lestari, 2013, Analisis Perbandingan Pengaruh Endorser Terhadap Sikap pada Merek Shampo Sunsilk dan Shampo Pantene, Jurnal Ilmu Manajemen, Vol. 1, No. 1, hal : 329-341.

Royan, Frans, 2004, Marketing Celebrities, Jakarta : Elex Media Komputindo

Sari, Dinny Puspita dan Edin S. Djatikusuma, 2013, Pengaruh Celebrity Endorser Ayu Ting Ting Dalam Iklan Televisi Terhadap Brand Image Produk Mie Sarimi, Skripsi, Jurusan Manajemen STIE MDP Business School, Palembang. Diakses dari www.eprints.mdp.ac.id tanggal 12 Desember 2013.

Shimp, A. Terence, 2003, Promosi dan Periklanan, Alih Bahasa Revyani Sjahrial, Erlangga, Jakarta.

Simamora, Bilson, 2008, Panduan Riset Perilaku Konsumen, Gramedia Pustaka Utama, Jakarta.

Soesatyo, Natalia dan Lenoid Julivan Rumambi, 2013, Analisa Credibility Celebrity Endorser Model : Sikap Audience Terhadap Iklan Dan Merek Serta Pengaruhnya Pada Minat Beli "Top Coffee", Jurnal Strategi Pemasaran, Vol, 1 No. 2, hal : 1 - 12.

Sugiyono, 2010, Statistika Untuk Penelitian, Bandung : Alfabeta.

Suhandang, 2008, Periklanan Manajemen, Kiat dan Strategi, Nuansa, Bandung

Sumarwan, Ujang, 2004, Perilaku Konsumen Teori Penerapannya Dalam Pemasaran, Jakarta : Ghalia Indonesia.

Tjiptono, Fandy, 2005, Periklanan Yang Efektif, Yogyakarta : Andi

Umar, Husein, 2004, Manajemen Riset dan Perilaku Konsumen, Jakarta : Gramedia Pustaka Utama.

Widodo, Iwan, 2013, Pengaruh Celebrity Endorser Terhadap Keputusan Pembelian Sepeda Motor Merek Honda Vario, diakses dari ejournal.umpwr.ac.id/, tanggal 12 Desember 2013.

http://industri.bisnis.com/read/20130401/12/5881/belanja-iklan-2013-diprediksi-capai-rp-124-triliun, diakses tanggal 9 Januari 2014 jam 15.38 WIB. 